\title{
Spatial-time variations in the distribution of atmospheric methane at high latitudes of the northern hemisphere
}

\author{
Sardana Vasileva \\ ${ }^{1}$ Yu.G. Shafer Institute of Cosmophysical Research and Aeronomy of Siberian Branch of the \\ Russian Academy of Sciences, Yakutsk, Russia
}

\begin{abstract}
A preliminary study of spatio-temporal variations of methane distribution at high latitudes of the northern hemisphere was conducted based on AIRS and JR-STATION data. The analysis showed a noticeable increase $(\sim 4 \%)$ in the methane concentration in the lower layers of the atmosphere and upper layers of the troposphere. According to the AIRS data, winter (February) and summer (July- August) peaks of the methane concentration were reported in the seasonal cycle of 2004-2018. Seasonal methane variations in the upper troposphere obtained from AIRS data have similarities to ground observations, but with a smaller amplitude
\end{abstract}

\section{Introduction}

In recent decades, significant warming has been observed at high latitudes of the northern hemisphere [1]. Climate change has a significant impact on methane $(\mathrm{CH} 4)$ sources. The global warming potential of $\mathrm{CH} 4$ exceeds 20 times the warming potential of $\mathrm{CO} 2$ [2]. The air temperature directly affects the sources of $\mathrm{CH} 4$ in the soil by affecting the metabolic rate of methanogens [3], as well as indirectly - through the melting of permafrost and changes of groundwater's depth and snow cover characteristics [4]. Other climatic changes in the Arctic may increase the intake of $\mathrm{CH} 4$ into the atmosphere due to the possible destabilization of methane hydrates in oceanic sediments [5].

The rapid pace of climate change in high latitudes and the expansion of anthropogenic activity in the Arctic in the future may lead to a significant increase in $\mathrm{CH} 4$ emissions into the atmosphere. Which can contribute to an increase in the rate of heating of the atmosphere. Under the current conditions, it is very important to conduct studies of variations in atmospheric methane.

The aim of this work is to study the spatiotemporal variations in the distribution of atmospheric methane at high latitudes of the northern hemisphere.

\section{Materials}

To analyze spatio-temporal dynamics of CH4 concentration during 2004-2018 data from the AIRS (Atmospheric Infrared Sounder) radiometer installed on the AQUA satellite (AIRX3STM product, https://giovanni.gsfc.nasa.gov) was used. The data for the $400 \mathrm{hPa}$ pressure level were used in this study, due to the sensor's maximum sensitivity to $\mathrm{CH} 4$ at this 
level. In the middle and high latitudes of the Northern Hemisphere, it reaches 400-300 hPa (about 7-9 km) [6].

Data from the JR-STATION greenhouse gas monitoring network for 2004-2018 were also used in the analysis (http://db.cger.nies.go.jp/portal/). The greenhouse gasmonitoring network is located in Western Siberia. [7].

\section{Results and discussion}

An area covering a part of the West Siberian Plain and the Central Siberian Plateau $\left(60^{\circ}-73^{\circ}\right.$ s.w., $68^{\circ}-126^{\circ}$ v.d.) was selected for research. In Fig. 1, black lines limit the sector of the studied area, the locations of four ground stations of the JR-STATION network are shown by dots: Igrim, Noyabrsk, Demyansk, Karasevoye.

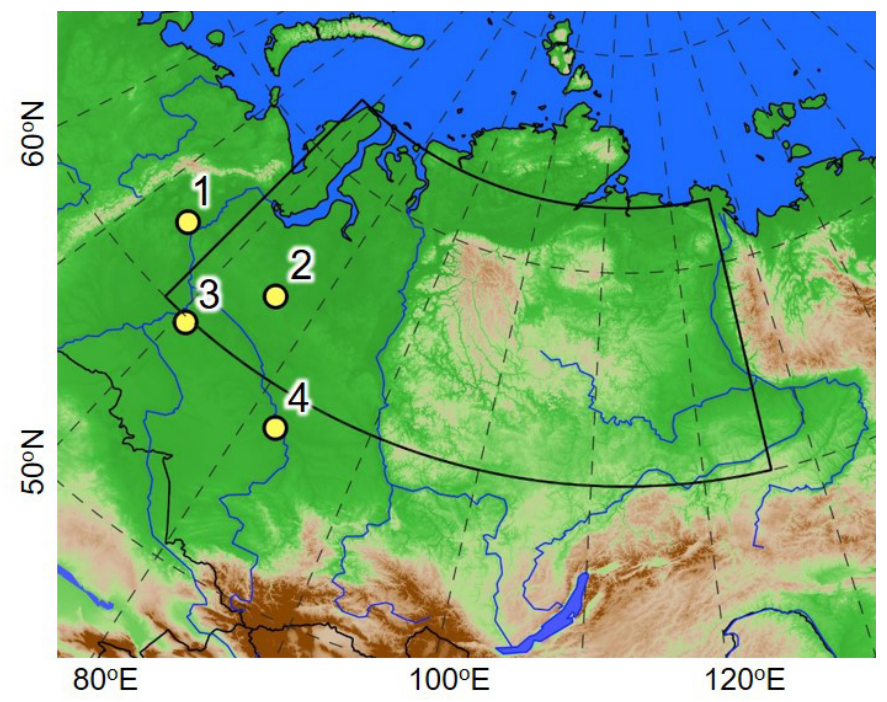

Fig. 1. Location of the test site and ground stations: 1- Igrim, 2- Noyabrsk, 3-Demyansk, 4Karasevoye

Inter-annual and seasonal variations of methane concentration from satellite and ground data are presented in Fig. 2a. As it can be seen from Fig. 2a, the concentration of CH4 increases at the surface level and upper troposphere; the total increase during the study period according to AIRS data was $\sim 67 \mathrm{ppb}$, according to ground data $\sim 86 \mathrm{ppb}$.

Fig. 2b shows seasonal variations in $\mathrm{CH} 4$ content from satellite and ground data for 2004-2018. There are two maxima in the surface layer: winter (February) and summer (JulyAugust) and two minima: spring (May) and autumn (October) [7, 8]. The methane concentration increase in the summer period has been recorded since the beginning of May, when the soil temperature increases and contributes to the increase in the activity of methanogenic microorganisms and reaches its peak in July-August, showing the seasonal CH4 emissions from swamp ecosystems [9]. Seasonal variations of methane content in the upper troposphere are similar to variations in the lower troposphere but have smaller amplitude. In the upper troposphere, there is also a winter maximum (January) and a summer increase in methane concentration. The spring minimum of concentration also occurs in May, but the winter minimum (December) is less pronounced. One of the explanations for the 
summer increase of methane in the upper troposphere may be an increase in vertical transport from the lower troposphere in summer [10]. Also in [11], the authors showed that in the summer, remote sources in Europe, North America, and Asia may contribute to the methane content.
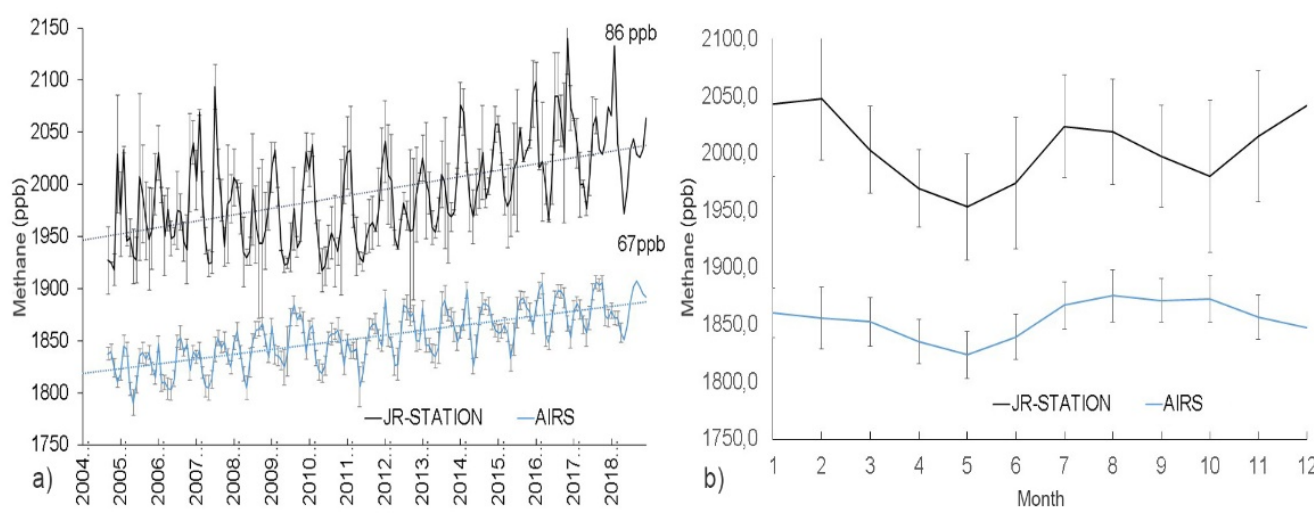

Fig. 2: a) Inter-annual variations of methane concentration, b) seasonal course of methane concentration according to AIRS data at $400 \mathrm{hPa}$ pressure level and averaged for 4 stations JR-STATION data

\section{Conclusion.}

Analysis of spatio-temporal variations in the distribution of atmospheric methane at high latitudes of the Northern Hemisphere in 2004-2018 showed that there is a noticeable increase $(\sim 4 \%)$ in the concentration of methane in the lower atmosphere and upper troposphere. According to the ground data, the seasonal cycle of methane concentration during the study period has winter (February) and summer (July- August) peaks. In the upper troposphere, seasonal variations in methane content have similarities, but also a smaller amplitude. In the upper troposphere, there is also a winter maximum (January) and a summer increase in the concentration of methane. The spring minimum of concentration also occurs in May, but the winter minimum (December) is less pronounced.

\section{References}

1. Climate Change 2013: The Physical Science Basis. IPCC Working Group I Contribution to AR5. P. 465-570 (Bern, Switzerland, 2016).

2. Отчет Межправительственной группы Экспертов по Изменениям Климата (МГЭИК), 2007 // http://www.ipcc.ch/pdf/assessment-report/ar4/syr/ar4 syr ru.pdf.

3. Christensen, T. R., Ekberg, A., Ström, L., Mastepanov, M., Panikov, N., Öquist, M., Svensson, B. H., Nykänen, H., Martikainen, P. J., and Oskarsson, H.: Factors controlling large scale variations in methane emissions from wetlands, Geophys. Res. Lett., 30, 1414, doi:10.1029/2002GL016848, 2003.

4. Khvorostyanov, D.V., Ciais, P., Krinner, G. and Zimov, S.A. Vulnerability of east Siberia's frozen carbon stores to future warming. Geophys. Res. Lett. 35, doi: 10.1029/2008GL033639. 2008. 
5. Shakhova, N., Semiletov, I., Salyuk, A., Yusupov, V., Kosmach, D., and Gustafsson: Extensive Methane Venting to the Atmosphere from Sediments of the East Siberian Arctic Shelf, Science, 327, 1246-1250, doi:10.1126/science.1182221, 2010.

6. Xiong X., Barnet C., Maddy E., Sweeney C., Liu X., Zhou L. and Goldberg M. Characterization and validation of methane products from the Atmospheric Infrared Sounder (AIRS) // Journal of Geophysical Research. Vol. 113. 2008. P. 1-14.

7. Sasakawa M., Shimoyama K., Machida T. et al. Continuous measurements of methane from a tower network over Siberia. Tellus B, 2010, vol. 62, pp. 403-416.

8. Arshinov, M.Y., Belan, B.D., Davydov, D.K. et al. Spatial and temporal variability of $\mathrm{CO} 2$ and $\mathrm{CH} 4$ concentrations in the surface atmospheric layer over West Siberia. Atmos Ocean Opt 22, 84-93 (2009). https://doi.org/10.1134/S1024856009010126

9. Kim, H.-S.; Maksyutov, S.; Glagolev, M.V.; Machida, T.; Patra, P.; Sudo, K.; Inoue, G. Evaluation of methane emissions from West Siberian wetlands based on inverse modeling. Environ. Res. Lett. 2011, 6, 035201.

10. Xiong, X., Barnet, C. D., Zhuang, Q., Machida, T., Sweeney, C., and Patra, P. K. (2010), Mid-upper tropospheric methane in the high Northern Hemisphere: Spaceborne observations by AIRS, aircraft measurements, and model simulations, J. Geophys. Res., 115, D19309, doi:10.1029/2009JD013796.

11. Мордвин, Е. Ю. Метан в атмосфере Западной Сибири : [монография] / Е. Ю. Мордвин, А. А. Лагутин ; АлтГУ. - Барнаул : [Азбука], 2016. - 148 с. : ил. 